\title{
Effect of cooking and of amino acid supplementation on the nutritive value of black beans (Phaseolus vulgaris L.)*
}

\author{
By R. BRESSANI, L. G. ELfAS AND ANA TERESA VALIENTE \\ Institute of Nutrition of Central America and Panama (INCAP), Guatemala, CA
}

(Received I9 March 1962-Revised I7 September 1962)

The leguminous seeds, particularly beans (Phaseolus vulgaris L.), are very important sources of protein in the diets of Latin American populations of low economic status. In Central America, beans provide from 20 to $30 \%$ of the protein in the diet and are second only to maize as a staple food (Flores, $196 \mathrm{I}$ ). Therefore, it is very important to the people of this area to evaluate the proteins in beans and to improve their nutritive value by correcting their amino acid deficiencies through supplementation with other foods.

Previous studies (Bressani, Marcucci, Robles \& Scrimshaw, 1954) dealt with the chemical composition and the content of essential amino acids of samples of leguminous seeds from several Central American countries. In another study, Bressani, Elias \& Navarrete (196r) compared the essential amino acid compositions of six samples of beans with the FAO protein reference pattern (FAO, I957), and came to the conclusion that methionine is the most limiting amino acid, followed by leucine and tryptophan as the second and third. It was of interest, therefore, to find out whether the order of limiting amino acids calculated from the FAO protein reference pattern could be corroborated by biological trials. Further, since beans are cooked to make them palatable and to free them of toxic effects (Eheart \& Sholes, 1948; Jaffé, Planchart, Páez Pumar, Torrealba \& Franceschi, 1955), it was also of interest to study the effect of cooking on their nutritive value. The work described here was undertaken to determine the limiting amino acids in cooked beans and the effect of the duration of cooking on the biological value of their proteins.

\section{EXPERIMEN'TAL}

\section{Materials and methods}

The leguminous seed used in all the experiments was a variety of black beans (Phaseolus vulgaris L.) grown in the town of San Pedro Ayampuc, Guatemala. The raw material was stored at $4^{\circ}$ until used.

Cooking. To find the optimum conditions for cooking beans, batches of I kg each of raw beans mixed with 21 . water were cooked in the autoclave for $10,20,30,40,60$, $90,120,150$ or $180 \mathrm{~min}$ at $16 \mathrm{lb}$ pressure $\left(121^{\circ}\right)$ in two experiments. The resulting materials were dried by a stream of hot air at $80^{\circ}$ for $18 \mathrm{~h}$ and then ground in a Wiley mill to pass a 40 -mesh sieve. The nine bean-flour samples were then stored under 
refrigeration until needed. Bean flour for the studies on the level of protein intake and on supplementation with amino acids was then prepared by pressure cooking for the optimum time ( $10 \mathrm{~min}$ ). A batch of beans was also cooked in an open kettle for $4 \mathrm{~h}$, which is the method used by the rural population in Guatemala. Pressure cooking rather than open-kettle cooking was used in the preparation of the standard bean flour because the former is the technique preferred for the commercial production of cooked bean flour and because the quantities prepared were larger and hence the variability that can occur between different batches when the open-kettle method is used was less.

Analysis of bean flour. Nitrogen was determined by the Kjeldahl method (Association of Official Agricultural Chemists, 1950) and the contents of lysine, methionine, and valine were measured by microbiological methods described earlier (Bressani et al. 1961). The content of free $\epsilon$-amino groups of lysine was determined by the dinitrofluorobenzene method (Conkerton \& Frampton, 1959).

\section{Experiments with rats}

Diets. Two of the experiments were to determine the effect of cooking time on the nutritive value of bean protein. The protein level was adjusted to about $15 \%$ of the diets, which consisted of $(\%)$ : beans $73 \cdot 3 \mathrm{I}$, mineral mixture (Hegsted, Mills, Elvehjem \& Hart, 194I) $4^{\circ} \circ 0$, cod-liver oil $\mathrm{I}^{\circ} 00$, cottonseed oil $5^{\circ} \circ 0$, and sufficient maize starch to adjust to roo. All diets were supplemented with $5 \mathrm{ml}$ of a vitamin solution to provide vitamins at the levels used by Manna \& Hauge (1953).

In other biological trials, the protein efficiency ratio (PER) of bean flour was determined with rats by giving them diets containing bean protein at different levels between Io and $18 \%$. The diets contained $46 \cdot 0,55 \cdot 0,64.5,73.34$ or $82.5 \%$ cooked bean flour and all were supplemented as before, maize starch being added to adjust to $100 \%$. For the studies on supplementation with amino acids, the protein level of the diet was around I2 \%. The basal diet contained $55.0 \%$ cooked bean flour and was supplemented with other nutrients as before. The supplementary amino acids were added to the basal diet to replace an equal weight of maize starch.

Rats. The rats used were of the Wistar strains from the INCAP colony.

Protein efficiency ratio. The numbers of groups, each of which consisted of three males and three females, used in each experiment are shown in Tables I-4. The animals within each sex were distributed at random among the several experimental groups. The mean initial weight of the animals was between 40 and $5 \circ \mathrm{g}$ and the mean weight among the groups differed by not more than $\mathrm{r} g$. The animals were kept in individual, all-wire screen cages with raised screen bottoms. Food and water were given ad lib. All experiments lasted 28 days; gains in weight and food intake were recorded weekly. At the end of the experimental period the PERs ( $g$ gain/g protein intake) were calculated. Blood samples were taken from some animals for the determination of serum proteins by the methods of Lowry \& Hunter (1945).

Balance experiments. Protein digestibility and biological value were studied with fifteen adult male rats weighing between 250 and $300 \mathrm{~g}$, divided into five diet-groups of three animals each (as shown in Table 6). The animals were given a 3 -day adaptation period which preceded the balance study of 4 days on each experimental diet. The 
animals were kept in individual metabolism cages and were offered $10 \mathrm{~g}$ daily of the diets under test; faeces and urine were collected daily and stored under refrigeration. In the first balance, endogenous nitrogen was determined experimentally by giving the same animals $10 \mathrm{~g}$ daily of a nitrogen-free diet consisting of $89 \%$ maize starch, $5 \%$ mineral mixture (Hegsted et al. I94I), I \% cod-liver oil, $5 \%$ cottonseed oil, and $5 \mathrm{ml} / \mathrm{r}$ oo $\mathrm{g}$ of the vitamin solution of Manna \& Hauge (1953). Other diets tested were the basal diet used for the supplementation studies and some of the bean-flour diets supplemented with amino acids. Nitrogen determinations in the diets, faeces and urine were made by the Kjeldahl method (Association of Official Agricultural Chemists, 1950). The formula used to calculate the true digestibility was: (nitrogen intake - faecal nitrogen + endogenous faecal nitrogen) $\div$ nitrogen intake $\times 100=$ true digestibility $(\%)$. The biological value was calculated according to the formula of Mitchell (1923-4).

Table I. Effect of the duration of pressure cooking on the nutritive value of beans for rats

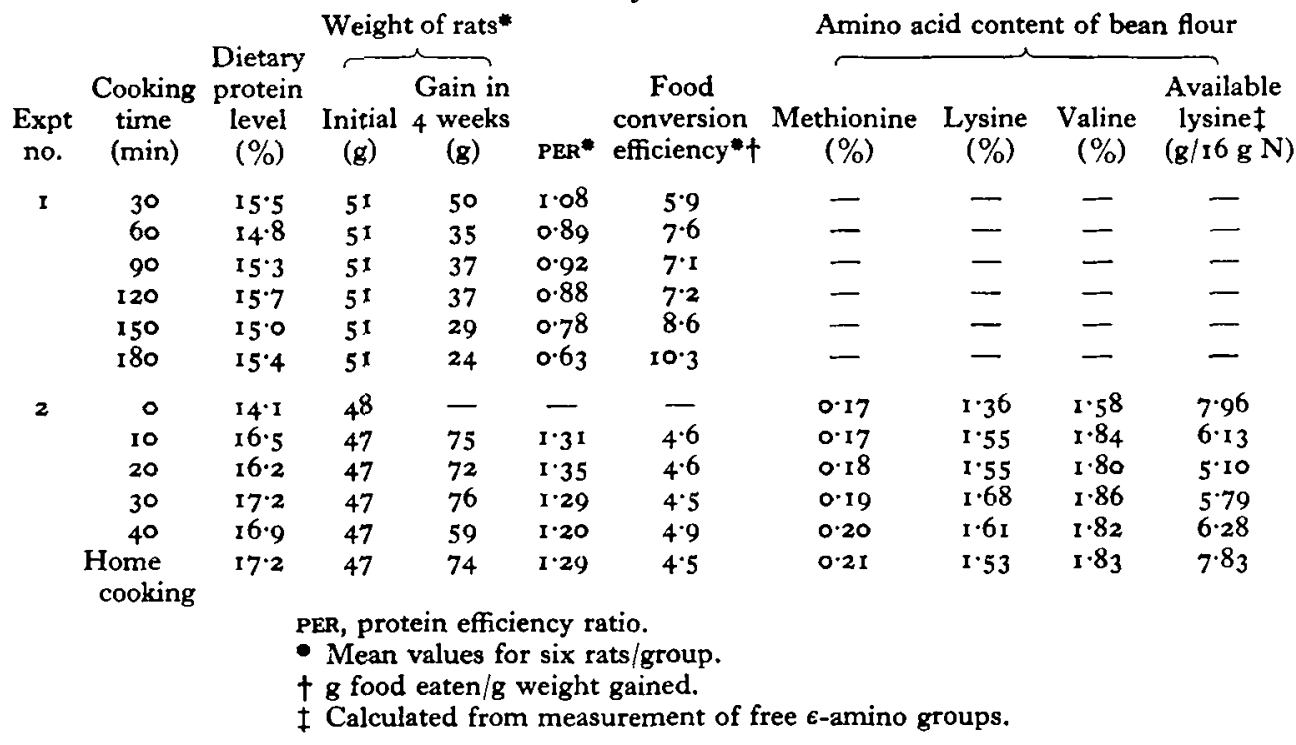

\section{RESULTS}

Effect of cooking. Table I shows the effect of cooking on the nutritive value of black beans, and also the contents of lysine, methionine, valine and available lysine (free $\epsilon$-amino lysine groups) in the raw and cooked black-bean flour. Whereas rats given cooked-bean diets showed varying rates of weight gain, all those given raw-bean diets alone or supplemented with methionine died in less than 14 days. Judged by the weight gains of the rats during 28 days and by the values of PER, pressure cooking for ro- 30 min did not decrease the nutritive value of the beans, but cooking for more than $30 \mathrm{~min}$ did. The differences in weight gain and PER between similar groups in the two experiments could be attributed to the percentage of protein in the diet, which was higher in the 
second experiment. Home cooking for $4 \mathrm{~h}$ in an open kettle did not decrease the nutritive value of beans. No apparent change in the methionine, lysine or valine content of the bean flour resulted from any method of cooking. The content of free $\epsilon$-amino groups of lysine, however, decreased in the pressure-cooked samples, except the 40 min sample, but not in those cooked in the open kettle.

Effect of protein level. Table 2 gives the results of increasing the protein level in the diets with bean-flour protein, as well as the effect of the addition of methionine at several levels. The highest PER was obtained with $16.7 \%$ protein in the diet, although better gain in weight resulted with $18.5 \%$. Statistical analysis of the results showed that the differences in mean weight gain and PER at different protein levels were highly significant.

Table 2. Effect of the dietary level of bean protein and of supplementation of the diets with methionine on the weight gain of rats

(Mean values for six rats/group)

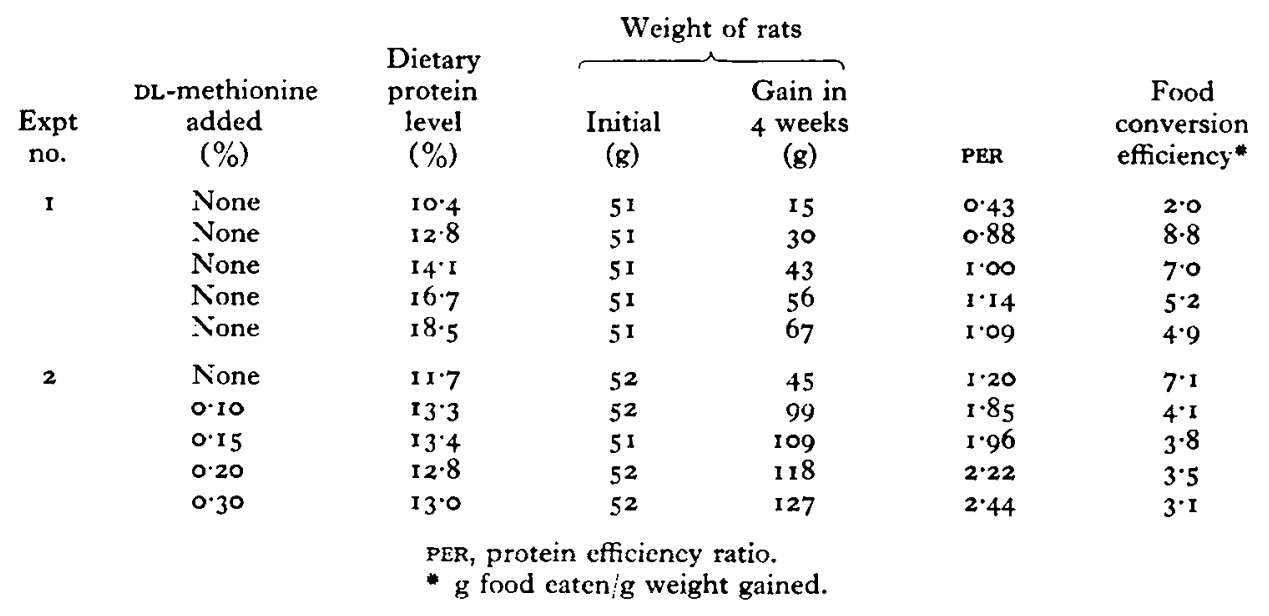

Table 2 also shows that the addition of $0.10 \%$ DL-methionine resulted in a significant increase in both weight gain and PER. Greater additions of methionine resulted in further increases in weight gain and PER. The increments were, however, proportionately smaller when compared with those resulting from supplementation with $0.10 \%$ DL-methionine.

Effect of addition of amino acids. Comparison of the essential amino acid composition of this variety of beans with that of the FAO protein reference pattern (FAO, 1957) suggested that methionine (with cystine) is not the only amino acid in which the beans are deficient, although it is the most limiting. Leucine and tryptophan appeared to be the second and third, respectively. For this reason, the effect of adding leucine and tryptophan, as well as other amino acids, was tested in biological trials.

Table 3 shows the effect of supplementing the basal diet plus methionine with other individual amino acids. None of the other amino acids improved the weight gain of the rats beyond the value obtained with methionine alone. Tryptophan and lysine 
additions, however, improved PER beyond the value obtained with the addition of methionine alone. The total protein content of serum increased with addition of methionine, and other amino acids added in the presence of methionine did not increase this value.

Table 3. Effect on the weight gain of rats and their serum protein content of supplementation of a bean diet with methionine alone or with another amino acid

\begin{tabular}{|c|c|c|c|c|c|}
\hline \multicolumn{6}{|c|}{ (Mean values for six rats/group) } \\
\hline Amino acid added & $\begin{array}{l}\text { Diet } \\
\text { no. }\end{array}$ & $\begin{array}{c}\text { Gain in } \\
\text { weight in } \\
4 \text { weeks } \\
\text { (g) }\end{array}$ & PER & $\begin{array}{c}\text { Food } \\
\text { conversion } \\
\text { efficiencyt }\end{array}$ & $\begin{array}{c}\text { Serum } \\
\text { proteins } \\
(\mathrm{g} / 100 \mathrm{ml})\end{array}$ \\
\hline \multirow{2}{*}{$\begin{array}{l}\text { None } \\
\text { Methionine }\end{array}$} & $\mathbf{I}$ & 45 & $I \cdot 20$ & $6 \cdot 60$ & 5.05 \\
\hline & 2 & 124 & $2 \cdot 27$ & $3 \cdot 50$ & $5 \cdot 80$ \\
\hline $\begin{array}{l}\text { Methionine, } \\
\text { DL-leucine }\end{array}$ & 3 & 126 & $2 \cdot 02$ & 3.50 & $5 \cdot 91$ \\
\hline $\begin{array}{l}\text { Methionine, } \\
\text { DL-tryptophan }\end{array}$ & 4 & 129 & $2 \cdot 42$ & $3 \cdot 31$ & $5 \cdot 63$ \\
\hline $\begin{array}{l}\text { Methionine, } \\
\text { L-lysine hydrochloride }\end{array}$ & 5 & I 28 & $2 \cdot 43$ & $3 \cdot 22$ & 5.62 \\
\hline $\begin{array}{l}\text { Methionine, } \\
\text { DL-valine }\end{array}$ & 6 & I33 & $2 \cdot 37$ & $3 \cdot 34$ & $5 \cdot 66$ \\
\hline $\begin{array}{l}\text { Methionine, } \\
\text { DL-phenylalanine }\end{array}$ & 7 & 129 & $2 \cdot 30$ & $3 \cdot 35$ & - \\
\hline $\begin{array}{l}\text { Methionine, } \\
\text { DL-isoleucine }\end{array}$ & 8 & 124 & $2 \cdot 28$ & $3 \cdot 49$ & - \\
\hline \multirow[t]{2}{*}{$\begin{array}{l}\text { Methionine, } \\
\text { vL-threonine }\end{array}$} & 9 & × 26 & $2 \cdot 32$ & $3 \cdot 30$ & 一 \\
\hline & R, pro & $\begin{array}{l}\text { ficiency } \mathrm{r} \\
\mathrm{L}-\mathrm{methion} \\
\mathrm{h} / \mathrm{g} \text { weight }\end{array}$ & 1 & others. & \\
\hline
\end{tabular}

Table 4 summarizes the result of supplementing the diet with combinations of the amino acids already tested individually with methionine. The various combinations did not improve rate of weight gain, but several of them when added to the methioninesupplemented bean diet resulted in an increase in PER. They were leucine plus tryptophan, leucine plus lysine, tryptophan plus lysine, and lysine plus valine. The effects of these combinations were similar, as indicated by statistical analysis of both weight gain and PER by Duncan's (1955) multiple-range test shown in Table 5. The addition of the non-essential amino acids, glutamic acid and glycine, or of all the amino acids, did not improve weight gain or PER more than the addition of methionine alone. In another experiment not reported here, the addition of eight amino acids, DL-methionine, L-lysine hydrochloride, DL-leucine, DL-tryptophan, DL-valine, DL-isoleucine, DL-phenylalanine and DL-threonine, adjusted to the levels of these amino acids in skim milk for a dietary protein content of $13.2 \%$, resulted in a mean weight gain of the rats of $133 \mathrm{~g}$ in 28 days, with a PER of $2 \cdot 28$, which is slightly less than that obtained with the addition of methionine alone.

Digestibility and biological value. Table 6 shows the results of measurements of digestibility and biological value. The diets supplemented with amino acids showed 
only a slight increase over the basal diet in the coefficient of true digestibility. The biological value, however, improved significantly with the addition of $0.20 \%$ of methionine. The addition of other amino acids to the basal diet did not improve the biological value beyond that obtained with the methionine supplement alone.

\section{Table 4. Effect on the weight gain of rats and their serum protein content of supplementa- tion of a bean diet with methionine and combinations of other amino acids}

(Mean values for six rats/group)

\begin{tabular}{|c|c|c|c|c|c|}
\hline Amino acid added* & $\begin{array}{l}\text { Diet } \\
\text { no. }\end{array}$ & $\begin{array}{l}\text { Gain in } \\
\text { weight in } \\
4 \text { weeks } \\
\text { (g) }\end{array}$ & PER & $\begin{array}{l}\text { Food } \\
\text { conversion } \\
\text { efficiencyt }\end{array}$ & $\begin{array}{c}\text { Serum } \\
\text { proteins } \\
\left(\mathrm{g}_{i}^{i} 100 \mathrm{ml}\right)\end{array}$ \\
\hline Methionine & 2 & 124 & $2 \cdot 27$ & 3.50 & $5 \cdot 80$ \\
\hline $\begin{array}{l}\text { Methionine, DL-leucine, DL- } \\
\text { tryptophan }\end{array}$ & 10 & 109 & $2 \cdot 17$ & $3 \cdot 65$ & $5 \cdot 42$ \\
\hline $\begin{array}{l}\text { Methionine, DL-leucine, L-lysine } \\
\text { hydrochloride }\end{array}$ & I I & I 3 I & $2 \cdot 39$ & $3 \cdot 24$ & $5 \cdot 72$ \\
\hline $\begin{array}{l}\text { Methionine, L-lysine hydrochloride, } \\
\text { DL-tryptophan }\end{array}$ & 12 & I 29 & $2 \cdot 4^{8}$ & $3 \cdot 33$ & $5 \cdot 71$ \\
\hline $\begin{array}{l}\text { Methionine, L-lysine hydrochloride, } \\
\text { DL-valine }\end{array}$ & 13 & 129 & $2 \cdot 49$ & $3 \cdot 18$ & $5 \cdot 3^{8}$ \\
\hline $\begin{array}{l}\text { Methionine, DL-leucine, L-lysine } \\
\text { hydrochloride, DL-tryptophan, } \\
\text { DL-valine }\end{array}$ & 14 & 122 & $2 \cdot 30$ & $3 \cdot 47$ & 一 \\
\hline Methionine, L-glutamic acid, glycine & 15 & I3I & $2 \cdot 20$ & 3.53 & - \\
\hline
\end{tabular}

\section{DISCUSSION}

The detrimental effect of high temperatures on the nutritive value of protein is a well-known fact ((USA) National Research Council: Food and Nutrition Board, 1950). However, the cooking of beans destroys the toxic factor, making them edible, though excessive cooking may destroy some of the nutritive value of their proteins as shown in this study. For the variety of beans used, the optimum cooking time was from 10 to $30 \mathrm{~min}$; after that, there was a progressive decrease both in the weight-gain curve of the rats and in the PER, indicating that the nutritive value of this protein had been harmed.

The fact that the animals given the raw-bean diet died during the first 2 weeks of the experiments shows clearly the presence of a highly toxic compound in this staple food, possibly a trypsin inhibitor, found also by other investigators in other varieties of leguminous seeds (Jaffé, 1950a; Jaffé et al. 1955). The first sign was diarrhoea, followed by refusal of the diet and, soon afterwards, death.

In the studies on supplementation with amino acids, methionine was the most limiting amino acid, as has been demonstrated by several investigators (Jaffé, I949, I950b; Russell, Taylor, Mehrhof \& Hirsch, 1946; Schneider \& Miller, 1954; Sherwood, Weldon \& Peterson, I954). The addition of $0.20 \%$ methionine to the basal diet increased the gain in weight more than twice, and there was a significant improvement 


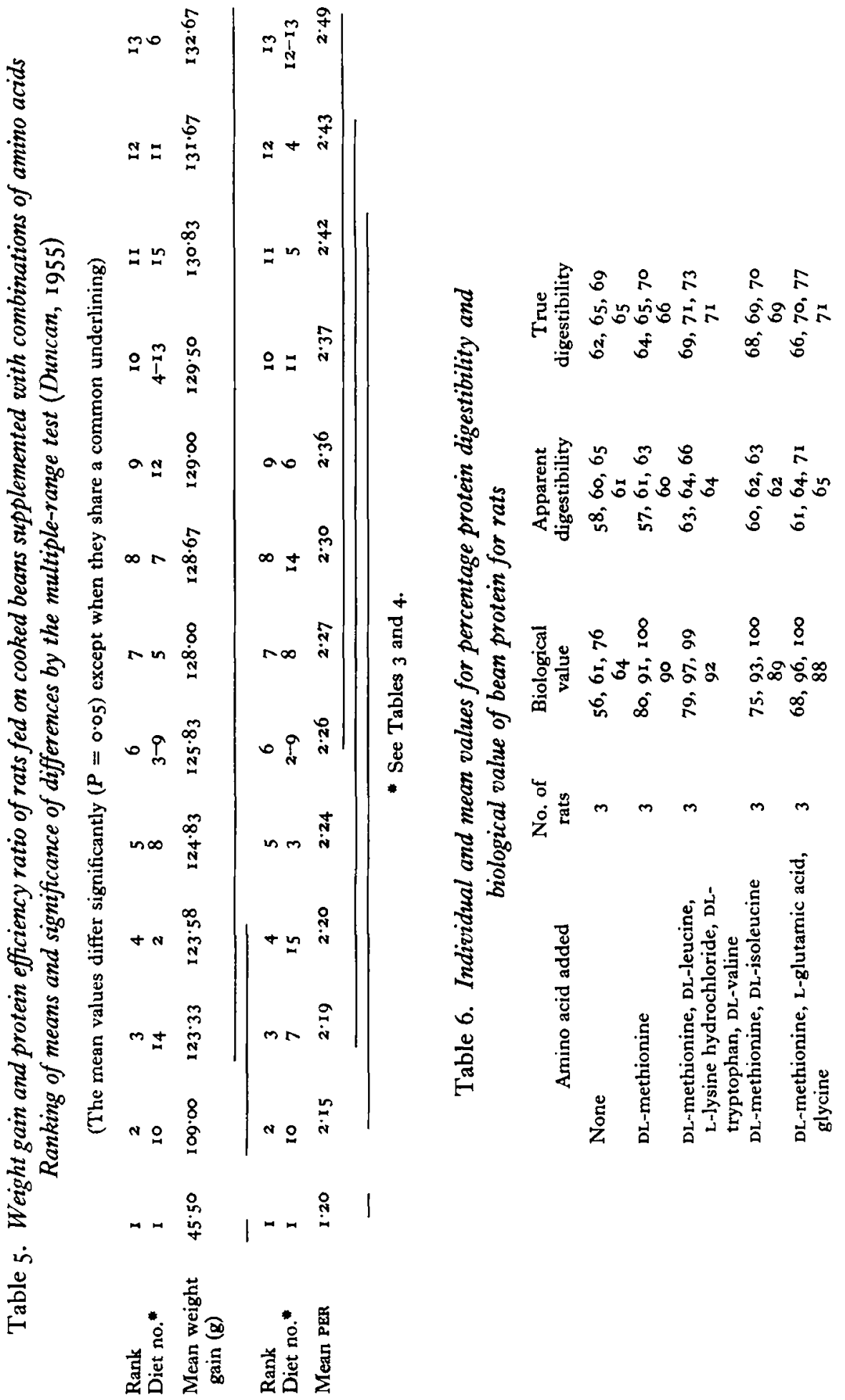


in the PER as compared to that with the basal diet. Addition of methionine at a level higher than $0.20 \%$ seemed to improve weight gain or PER only slightly.

The addition of other amino acids, except for lysine and tryptophan, to the basal diet already supplemented with methionine resulted, mostly, in no further beneficial effects beyond those obtained with methionine alone. Of the two amino acids found limiting by calculation, leucine and tryptophan, only tryptophan when added with methionine appeared to improve the nutritive value of this variety of bean, in spite of the fact that comparison with the FAO protein reference pattern indicated that both were limiting.

A response to supplementation with leucine was expected because of its deficiency in the beans as shown by comparison with the FAO protein reference pattern and because bean protein contains isoleucine and valine in such excessive amounts that when supplemented with leucine its nutritive value would be improved (Bressani et al. $\mathrm{I}_{96 \mathrm{I}}$ ). However, the results seem to indicate that in bean protein no imbalance exists, since supplements of isoleucine and valine were given separately to some experimental groups without any response.

Beans have been considered good sources of lysine and tryptophan (Bressani et al. 1954; FAO, 1953). The results of the studies described here indicate, however, that these amino acids are not biologically available in as large quantities as had been believed. Although the gains in weight and PER obtained with addition of lysine and tryptophan to the methionine-supplemented diet were not statistically different from the values observed with supplementation by methionine alone, it should be noted that the responses to lysine and tryptophan were in the extreme of the Duncan's multiple-range test of the results, as shown in Table 5 .

In studies of mixtures of maize and beans (Bressani, Valiente 8 Tejada, 1962), it was found that in even the best combination of these two staples lysine was limiting. The positive response to the addition of lysine and tryptophan to beans in this study, as judged by the better PER, may have been due to incomplete physiological availability of both amino acids in unsupplemented cooked beans given to the animal. This view is supported, at least for lysine, by the finding that there is a decrease in the content of free $\epsilon$-amino groups of lysine of the bean flour during cooking. The beneficial effect of the addition of these two amino acids to cooked beans supplemented with methionine was also observed when either was added individually or with other amino acids. Several possible factors, among which cooking temperature may be one, may explain this finding. The possible incomplete availability of the amino acids to the animal is substantiated by the low true digestibility of bean protein, which was not improved by supplementation with amino acids. The biological values further indicate that the absorbed protein was markedly deficient in methionine, since addition to the diet of this amino acid resulted in a significant increase in the biological value of bean protein but did not result in an increase in digestibility. 


\section{SUMMARY}

I. The effect of pressure cooking for various periods on the nutritive value of blackbean (Phaseolus vulgaris L.) protein was studied by chemical analysis and microbiological assessment of changes in methionine, lysine and valine contents, as well as by determination of free $\epsilon$-amino groups of lysine and biological tests with rats. The results indicated that cooking for from 10 to $30 \mathrm{~min}$ at $16 \mathrm{lb}$ pressure $\left(121^{\circ}\right)$ was optimal. Longer cooking times decreased the nutritive value of bean protein. Openkettle cooking for $4 \mathrm{~h}$ was found to be as good as pressure cooking within the ro-30 min period.

2. Rats fed on raw-bean diets with or without a methionine supplement died in less than 14 days. Cooking destroyed the toxic factor in beans.

3. The concentrations of lysine, methionine and valine, microbiologically determined, were not changed by cooking. On the other hand, the content of free $\epsilon$-amino groups of lysine decreased as cooking time increased. The first limiting amino acid in bean protein was found to be methionine, and the addition of $0.20 \%$ of this amino acid to the bean diet significantly improved the weight gain of the rats, the protein efficiency ratio and the biological value. The true digestibility of the protein was not improved by addition of methionine or other amino acids.

4. It was also found that the addition of lysine and tryptophan to the methioninesupplemented bean diet improved the PER but not the weight gain of the rats. This improvement in PER seems important since beans have always been considered good sources of both amino acids.

5. It is concluded that these amino acids are limiting in bean protein because of incomplete availability to the animal, as corroborated by the demonstrated low true digestibility of bean protein.

This investigation was supported by Grants RF-NRC-I from the (USA) National Research Council and A-98I from the (USA) National Institutes of Health.

The assistance of Dr Miguel A. Guzmán and Mr Constantino Albertazzi with the statistical analysis of results is gratefully acknowledged.

\section{REFERENCES}

Association of Official Agricultural Chemists ( 1950). Official Methods of Analysis, 7 th ed. Washington, D.C.: Association of Official Agricultural Chemists.

Bressani, R., Elías, L. G. \& Navarrete, D. A. (196r). F. Fd Sci. 26, 525.

Bressani, R., Marcucci, E., Robles, C. E. \& Scrimshaw, N. S. (1954). Food Res. 19, 263.

Bressani, R., Valiente, A. T. \& Tejada, C. E. (ig6z). F. Fd Sci. 27, 394.

Conkerton, E. J. \& Frampton, V. L. (1959). Arch. Biochem. Biophys. 81, I 30.

Duncan, D. B. (1955). Biometrics, 11, I.

Eheart, M. S. \& Sholes, M. L. (1948). Food Res. 13, 227.

FAO (1953). F.A.O. nutr. Stud. no. 9.

FAO (1957). F.A.O. nutr. Stud. no. 16.

Flores, M. (196r). Proc. int. Congr. Diet. IIr. London, p. 23.

Hegsted, D. M., Mills, R. C., Elvehjem, C. A. \& Hart, E. B. (1941). F. biol. Chem. 138, 459.

Jaffé, W. G. (1949). Proc. Soc. exp. Biol., N.Y., 71, 398.

Jaffe, W. G. (1950a). Proc. Soc. exp. Biol., N.Y., 75, 219.

Jaffé, W. G. (1950b). Arch. venez. Nutr. I, 107. 
Jaffé, W. G., Planchart, A., Páez Pumar, J. I., Torrealba, R. \& Franceschi, D. N. (1955). Arch. venez. Nutr. 6, 195 .

Lowry, O. H. \& Hunter, T. H. (1945). F. biol. Chem. 159, 465.

Manna, L. \& Hauge, S. M. (1953). F. biol. Chem. 202, 91.

Mitchell, H. H. (1923-4). F. biol. Chem. 58, 873 .

National Research Council: Food and Nutrition Board (1950). Repr. nat. Res. Coun., Wash., no. I31.

Russell, W. C., Taylor, M. W., Mehrhof, T. G. \& Hirsch, R. R. (1946). F. Nutr. 32, 3 I3.

Schneider, B. H. \& Miller, D. F. (1954). F. Nutr. 52, 58 r.

Sherwood, F. W., Weldon, V. \& Peterson, W. J. (1954). F. Nutr. 52, 199. 